and to the distribution of books-a symbol of this progress. The author rightly maintains that Newton's "Principia" is one of the great books which have laid the foundation of modern mathematics and astronomy and have influenced many aspects of the physical sciences as well as various phases of philosophy and religion. A brief outline of Newton's life is followed by a more detailed study of the "Principia" and its publication, with special reference to the third edition. An interesting section is devoted to the annotated and corrected editions of the "Principia" and includes an account of the so-called folio size copies of the third edition. In the statistical survey with which the article concludes, some seventy-two copies of the "Principia" and their locations are mentioned with appropriate references and comments. The whole forms an interesting and instructive piece of research both from the bibliographical and cultural points of view.

\section{Plant Growth Regulators}

The rapid expansion of our knowledge of the natural plant growth substances and the almost unprecedented success of the practical application of closely related synthetic chemical homologues in agriculture and horticulture have brought with them the usual terminology difficulties, which have unfortunately been aggravated by careless and ambiguous usage, particularly by workers in applied fields of research. Plant physiologists in general have been conscious of the need for a review of this terminology and for authoritative definitions based on modern knowledge and ideas on action and function in the plant. This need has perhaps been felt most strongly in the United States, where an American Society of Plant Physiologists study committee, composed of four leading workers in this field of research $(\mathrm{H} . \mathrm{B}$. Tukey, F. W. Went, R. M. Muir and J. van Overbeek), has, for the past two years, been drawing up a new classification to embrace all 'chemical regulators' in plants. They have rightly appreciated that the system should be of world-wide application and have invited comment on their draft scheme from plant physiologists in Great Britain. It is hoped that their final recommendations will be universally acceptable. Their task is no light one since, for example, there are some who might even oppose the use of the term 'regulator' for the many compounds that merely act as cell poisons albeit below the lethal threshold. However, when finally framed and accepted, it should be rigidly applied by all. We must remember, however, that no matter how well it may suit our present needs it cannot be more than an interim classification, and will need further revision as we increase and deepen our knowledge of the exact function and mode of action of these compounds in cell and tissue.

\section{Water Problems in Dutch Agriculture}

A LECTURE entitled "Lack of Water in a Land of Water", delivered in the international language under the auspices of the British Esperantist Scientific Association, was given by Dr. G. F. Makkink, of the Central Institute for Agricultural Research, Wageningen, on October 21 at University College, London. Dr. Makkink dealt with the problems facing agriculture in the Netherlands as a result of low rainfall combined with the excessive porosity of the soil and also as a result of the ingress of salt water. This latter factor occurs not only by seepage through the dykes but also at the sea-locks and (in dry seasons) by penetration of salt water up the estuaries. He stated, for example, that the sea-locks at Amsterdam admit daily $21 \times 10^{5} \mathrm{kgm}$. of salt into the Zuider $Z_{e e}$, and that during a dry season $24 \times 10^{7} \mathrm{kgm}$. of salt may enter the estuaries daily and not return; during 1949 salt water penetrated $45 \mathrm{~km}$. up the Waal River and threatened the economy of important areas. Dr. Makkink concluded by outlining the ambitious programme of works which is being undertaken not only to reclaim the land out to the are of the Frisian Islands but also partially to divert the Rhine waters into the Zuider $\mathrm{Ze \theta}_{\Theta}$ and thus form a huge reservoir of fresh water for agriculture and for use in the battle against the intrusions of sea water.

\section{National Central Library, London: Report for 1951-52}

The thirty-sixth annual report of the executive committee of the National Central Library, London, covers the year ended February 29, 1952 (pp. 22; published by the Library), and records an increase of the Treasury grant-in-aid from $£ 25,000$ to $£ 27,250$ for 1951-52; of this, $£ 1,000$ was to compensate for the discontinuance of the Carnegie United Kingdom 'Trust's contribution. Contributions from libraries of all types, adult class organizations and individuals increased by 40 per cent to $£ 5,210$. The Carnegie United Kingdom Trust has agreed to the merging in the Library's general account of the separate fund for the Union Catalogue of Periodicals in University Libraries. Total issues of books from or through the Library increased from 94,220 during $1950-51$ to 98,308 ; for the Scottish Central Library the corresponding figures are 12,616 and 15,708, and for the Irish Central Library for Students, 11,959 and 12,089. Total applications increased by $9 \cdot 3$ per cent, and $69 \cdot 37$ per cent were dealt with successfully, compared with $65 \cdot 3$ per cent during 1950-51. Issues to university libraries increased by 26.09 per cent, and those to outlier libraries, libraries of government departments, industrial and research organizations, and educational and cultural bodies also increased. University libraries lent 38,962 volumes under the national system. Loans made to foreign libraries remained at a high level ( 1,589 books to thirty-seven countries) ; but books borrowed from foreign libraries increased from 584 to 885 books from eighteen countries. The report refers to the need for extra funds for union cataloguing and the development of the outlier library system, as well as to progress in the union cataloguing of Russian books and periodicals available in Britain, and to the increased activities of the British National Book Centre in re-allocating 'unwanted' books and periodicals between British libraries and between libraries in Britain and those abroad. The reconstructed building of the National Central Library was opened by the Earl of Elgin in June 1952.

\section{Physics of Particle-Size Analysis: Conference in Nottingham}

The Institute of Physics is arranging a conference on "The Physics of Particle-Size Analysis", to be held in the University of Nottingham during April $6-9,1954$. It is anticipated that the various sessions will cover not only such fundamental physical processes as the fluid dynamics and the optics of particles and systems of particles, but also accounts of other phenomena encountered in particle-size analysis such as the aggregation and dispersion of particles in a fluid. Arrangements will be made also for a discussion on automatic methods of counting and 